\title{
Speaking in Tongues? Daimyo, Zen Monks, and Spoken Chinese in Japan, 1661-1711
}

\section{REBEKAH CLEMENTS}

The scholarly narrative of spoken Chinese studies in Tokugawa Japan is dominated by Ogyū Sorai, who founded a translation society in 1711 and urged Japanese intellectuals to learn contemporary spoken Chinese in order to draw closer to the language of the Chinese classics. This article explores the decades prior to this, when Sorai served the powerful daimyo Yanagisawa Yoshiyasu. By investigating Yoshiyasu's contact with Chinese monks and the surprising but previously untested claim that he could understand spoken Chinese, I explore the cultivation of spoken Chinese learning and the patronage of Chinese émigrés by members of Japan's warrior elite in the late seventeenth and early eighteenth centuries. Prior to the scholarly interest in vernacular Chinese and the popularity of Ming and Qing literature in Japan from the Kyōhō period (1716-35) onwards, Chinese orality served as a tangible link to the Chinese tradition for Yoshiyasu and other powerful daimyo, functioning as a sign of their fitness for power in East Asia.

Keywords: Buddhism, China, early modern, Japan, Ōbaku, vernacular Chinese, Yanagisawa Yoshiyasu

\section{INTRODUCTION}

$\mathrm{O}$ THE TWENTY-FOURTH day of the third month of 1708, during an era once regarded by historians as one in which Japan was isolated from foreign contact, an audience was held at the shogunal castle in Edo for Yuefeng Daozhang (Jp. Eppō Dōshō, 16551734), the Chinese abbot of the Manpukuji temple located near Kyoto. Speaking in Chinese, Yuefeng participated in a question-and-answer dialogue (mondō) about Zen Buddhism. A Japanese monk translated, but among those present was one of the most powerful daimyo of the day, Yanagisawa Yoshiyasu (1658-1714), who was said to have been the only Japanese audience member able to grasp the gist of what Yuefeng was saying without waiting for the translation. Is this account reliable, and if so, what explains an eighteenth-century Japanese daimyo's ability to understand spoken Chinese?

For the most part, a personal interest in learning foreign spoken languages was not shared by rulers in other parts of East Asia at this time and had not been a feature of the upper levels of Japanese governing classes since the early centuries of recorded history, when some may have spoken Chinese. Moreover, it is the classical Chinese written rather than spoken language that is understood as occupying a privileged position in Japan at this time. Yet in Yoshiyasu's day the public performance of spoken Chinese lectures for ruling elites was not uncommon. Yoshiyasu had his retainers, including the soon-to-be-famous of Modern Languages and Cultures at Durham University. 
Confucian scholar Ogyū Sorai (1666-1728), lecture in spoken Chinese on the Confucian classics during the many official visits (onari) by shogun Tokugawa Tsunayoshi (16461709) to Yoshiyasu's residence. Indeed, it was during his "apprenticeship" in the Yanagisawa house that Sorai acquired much of the vernacular Chinese knowledge and connections that were to be fundamental to his later career (Bodart-Bailey 2006, 241-43; Imanaka 1966, 76-90; Lidin 1973, 112-30).

It is well known that after leaving Yanagisawa employment, Sorai urged Japanese scholars to learn contemporary spoken Chinese in order to draw closer to the Chinese classics, and founded a translation society for the study of vernacular Chinese in 1711 (Pastreich 2001; Sorai 1977). Thanks to the work of postwar scholars like Maruyama Masao (1952), Sorai looms large in the modern narrative of spoken Chinese and studies of written vernacular Chinese in Tokugawa Japan. Also well known is the widespread interest in spoken and written vernacular Chinese among literate Japanese and the influence of vernacular Chinese fiction on the Japanese publishing industry from the Kyōhō period (1716-35) onwards. Seminal works on this phenomenon by Tokuda Takeshi (1987), Ōba Osamu (1967; 1980), and Okada Kesao (1991) form the backdrop to this study, and in recent years, a new generation of Anglophone scholars have also begun exploring the topic (Hedberg 2012; Jōo 2011; Nakamura 2011).

This article goes in a different direction by exploring Japanese interest in spoken Chinese prior to the vernacular Chinese "boom" that gained pace from the $1710 \mathrm{~s}$ onwards. This boom included Sorai's exhortations to the study of vernacular Chinese (Pastreich 2001), the mining of contemporary Chinese fiction by Japanese authors as inspiration for their own work (Tokuda 1987), and an increasing availability of vernacular Chinese dictionaries for Japanese readers (Okada 2006, 243-50).

Prior to this, could the daimyo Yoshiyasu really understand Chinese? Other members of Japan's warrior elite, including the shogun Tsunayoshi, the powerful daimyo Tokugawa Mitsukuni, and Governor of Bingo Makino Narisada, also sponsored the presence of Ming exiles in Japan and the study of spoken Chinese. What is the significance of these daimyos' support for spoken Chinese learning and Chinese speakers? This article seeks to answer these questions to better understand early modern Sino-Japanese relations, the nature of daimyo power, and the history of Chinese language learning in Japan.

\section{Yanagisawa YoshiYasu}

Yanagisawa Yoshiyasu, who rose from humble origins to become one of Japan's most powerful daimyo in the late seventeenth and early eighteenth centuries, is an intriguing figure whose role in politics and society has yet to be fully explored. There are popular accounts of Yoshiyasu (e.g., Fukutome 2011), but no scholarly biography has been published since 1921 (Hayashi 1921), although Miyakawa Yōko, one of the few scholars currently working on Yoshiyasu, has published several authoritative editions of works written in the Yanagisawa house (Miyakawa 2007, 2011, 2012, 2013, 2014). Given the relative scarcity of recent work on Yoshiyasu, it is worth briefly revisiting his biographical details here. He was born in Edo in 1658 to a minor retainer who served Tokugawa Tsunayoshi, who, as the fourth son of the reigning shogun, Iemitsu (1604-51), was not at that point likely to inherit his father's role but later became shogun after the early deaths of his 
elder brothers and their heirs. Yoshiyasu began his career as Tsunayoshi's pageboy but rose to become his favorite and trusted adviser. When Tsunayoshi became shogun, Yoshiyasu was promoted, eventually rising to daimyo status in 1688. In further recognition of his service, in 1701 Yoshiyasu was granted the right to use the family name Matsudaira, which was the family name of the Tokugawa house, having earlier been granted the character yoshi from Tsunayoshi for his personal name. Then, in 1704, Yoshiyasu, whose rice allowance as a daimyo had been steadily growing, was granted a vast fief in the domain of Kōfu in Kai Province (now part of Yamanashi Prefecture), which, since Tokugawa Ieyasu (1543-1616) founded the shogunate in 1603, had been held only by members of the Tokugawa family. The choice of the Kofu domain was also inspired by the fact that the Yanagisawa traced their lineage to Kai Province, where they had served the warlord Takeda Shingen (1521-73), entering the service of Tokugawa Ieyasu upon the death of Shingen in 1573. Although Yoshiyasu was too busy with his duties in Edo ever to visit his domain during his lifetime, the award of Kōfu was both an acknowledgment of Yoshiyasu's family history of loyalty to the Tokugawa house and evidence of just how far the young pageboy had come (Miyakawa 2007, 48-55; Walthall 2007, 178-80).

However, soon after Yoshiyasu's death in 1714, his reputation became the victim of his success. He was seen as an upstart who had risen to power by catering to the shogun Tsunayoshi's more notorious proclivities. Mock biographies and works of popular fiction were published in which Tsunayoshi and Yoshiyasu were accused of holding orgies in the shogunal castle; Yoshiyasu was said to have lent his concubine to Tsunayoshi and that Tsunayoshi was the real father of Yoshiyasu's heir, Yoshisato, as a result. Modern researchers have unearthed no basis for these claims (Bodart-Bailey 1979; Fukutome 2011; Walthall 2007). The public picture of Yoshiyasu that emerges instead is of an earnestly serious man who studied Buddhism and supported a stable of major scholars, many of whom are far better known today than their patron. They include Kitamura Kigin (1624-1705), who was the compiler of the first major printed collection of commentaries on the court classic Genji monogatari (The tale of Genji, 1008), and Ogyū Sorai, who became one of the most important Confucian scholars of his day. Other well-known scholars who worked for Yoshiyasu included the Confucian scholar Andō Tōya (16831719) and the literatus Hattori Nankaku (1683-1759).

The women of Yoshiyasu's household were likewise talented additions to his salon, and the Yanagisawa official record, Rakushido nenroku (Annual record of the Hall of Enjoyment), details participation by Yoshiyasu's mother, wife, and concubines in the exchanges of gifts and poetry that marked official celebrations. ${ }^{1}$ Among these women, particularly significant for our purposes here is a concubine, Ōgimachi Machiko (1679?-1724), who wrote an extensive account of Yoshiyasu's life called Matsukage nikki (In the shelter of the pine, c. 1710-12). Machiko, who was from a middle-ranking aristocratic family in Kyoto that traced its ancestry to the great classical Japanese scholar Sanjōnishi Sanetaka (1455-1537), was a highly educated woman and brought important court connections and cultural prestige to Yoshiyasu's house (Miyakawa 2007, 33-47;

\footnotetext{
${ }^{1}$ Miyakawa Yōko’s publication of a modern critical edition of Rakushidō nenroku is ongoing, and thus far covers the years 1658-1702 (Miyakawa 2011, 2013, 2014). In this article, I cite this modern edition where possible, and for events post 1702 I cite a 1915 manuscript copy held by the Historiographical Institute at the University of Tokyo (SHJ 1915).
} 
Rowley 2010, 49-55). Her Matsukage nikki draws extensively on The tale of Genji and depicts the Yanagisawa mansion as a latter-day version of the eponymous hero's Rokujō mansion; it is nevertheless a largely factual account and a useful source of information on Yoshiyasu's life. Machiko and her court culture were part of Yoshiyasu's carefully curated salon that became the location of classical Chinese and Japanese poetry gatherings, study groups, and calligraphic artistry in which Yoshiyasu's male and female family members participated, together with an array of talented house scholars and distinguished visitors (Miyakawa 2012; Shimauchi 2009). Many of its members and visitors spoke Chinese, and as we will see, the sounds of contemporary, spoken Chinese were one facet of the glittering cultural world cultivated by Yoshiyasu.

\section{Are the Accounts of Yoshiyasu Understanding Yuefeng's Lecture Reliable?}

If Yoshiyasu himself could understand spoken Chinese, this would supplement the current view of vernacular Chinese reception in Japan by shifting the focus back several decades prior to the founding of Sorai's school, and up a social class from scholars to the ruling warrior estate. The question of Yoshiyasu's putative Chinese abilities has not been resolved since it was touched upon over half a century ago in the work of Tsuji Zennosuke and Ishizaki Matazō, prewar pioneers of Buddhism and Tokugawa vernacular Chinese studies, respectively (Ishizaki 1940; Tsuji 1947, first delivered as a lecture in January 1924). Both claimed that Yoshiyasu could comprehend vernacular Chinese, and were more concerned with exploring his study of Buddhism or his sponsorship of vernacular Chinese learning than this possibility. Tsuji stated that Yoshiyasu "understood spoken Chinese well" (yoku tōon o kaishita) (Tsuji 1947, 248). Ishizaki, more circumspect, wrote that, in addition to having his retainers perform Chinese lectures, Yoshiyasu could "use vernacular Chinese language himself" (mizukara tōgo o ayatsuri), which could imply written, rather than spoken abilities (Ishizaki 1940, 52). Both briefly mention, among circumstantial evidence investigated in more detail below, the account in which Yoshiyasu understands Yuefeng's dialogue, Ishizaki citing Tsuji as the source of the anecdote (Ishizaki 1940, 50; Tsuji 1947, 249). But, as was common scholarly practice at the time he was writing, Tsuji listed a number of source texts for the paragraph in which he mentions the anecdote, and it is unclear which source goes with this important piece of information, or whether it is reliable.

The account in which Yoshiyasu understands Yuefeng speaking in Chinese, as cited by Tsuji, may in fact be traced to a nineteenth-century revisionary history of the daimyo's life, Kaishoshō Yoshiyasu ason jikki (True account of minister Yoshiyasu, the captain from Kai, undated manuscript) by the literatus Sakata Morotō (1810-75) (SHJ 1919, 59:14r). Sakata, who was a vassal of the Akizuki domain (now part of Fukuoka Prefecture) and after the Meiji Revolution worked for Japan's new Ministry of Foreign Affairs (Kokusho jinmei jiten 1995, 333), is possibly the first modern historian to set out to correct the salacious and now largely discredited reputation Yoshiyasu acquired posthumously. He based his eighty-one-volume manuscript history on hundreds of "credible source documents" (inshōsho) together with "dubious source documents" (nanshin inshosho), which were presumably used with caution. Unfortunately, Sakata only cites exact sources when he quotes verbatim, and the episode in which Yoshiyasu understands 
Yuefeng's speech is one of many where he does not name the source or sources he is relying upon. Nor does the incident appear in the two major records of Yoshiyasu's household: the official annals, Rakushido nenroku, and Matsukage nikki, the aforementioned account of Yoshiyasu's life written by his concubine Machiko. Thus, the paper trail of Yoshiyasu's understanding of Yuefeng's lecture ends—for now at least—with Sakata.

There are, however, sound reasons for taking Sakata's claim seriously. His history, although revisionary, is not hagiographic, and aims to be evidence-based. Moreover, Sakata himself viewed the anecdote with surprise, deeming it necessary to provide an explanatory note. This note surmises that Yoshiyasu may have understood the gist of Yuefeng's lecture because he had studied Zen and was used to hearing spoken Chinese, having hired a Nagasaki interpreter-one "Kuraoka Bunjirō Genshō" — to act as an interpreter in his meetings with visiting Chinese monks. Sakata notes that, in addition, many Yanagisawa retainers were interested in spoken Chinese and conducted dialogues (mondō) in Chinese, which Yoshiyasu would also have witnessed (SHJ 1919, 59:14r). Even if the notion that Yoshiyasu understood the gist of Yuefeng's lecture is an exaggeration, there probably had to be factors, like the ones Sakata suggests, for the claim to be made in the first place.

When revisiting the pioneering but for many years neglected work of Ishizaki (Imanaka 1966, 77), some modern scholars, such as Olof Lidin, have also noted the possibility that Yoshiyasu understood Chinese (Lidin 2011, 6; see also Bodart-Bailey 2006, 241; Lidin 1973, 114). But the true extent of Yoshiyasu's abilities, if any, remains untested, and the question of why he might have studied spoken Chinese is unanswered. In recent years, there has been new research on the activities of Chinese Zen (Ch. Chan) monks in Japan (Baroni 2000; Kimura 2005; Wu 2014a), and there are now several annotated critical editions of Matsukage nikki available (Masubuchi 1999; Miyakawa 2007; Ueno 2004), a valuable source of information on Yoshiyasu's life that was not used by Tsuji or Ishizaki. It is therefore worth revisiting the claims of Tsuji and Ishizaki, in the light of fresh evidence, in order to explore further the question of Yoshiyasu's possible Chinese abilities, and the significance of his and his shogun's interest in spoken Chinese studies.

\section{Speakers of Chinese in Tokugawa Japan-Merchants, Interpreters, and Ming Exiles}

One reason for the plausibility of Sakata's anecdote is that the seventeenth century brought increasing numbers of Japanese people into contact with speakers of Chinese. Although there were strict controls on the movement of foreigners (and indeed locals, too) during the period, there was also a large number of Chinese merchants, émigrés, and visitors in Japan. With the fall of the Ming dynasty in 1644, many scholars, monks, and artists took refuge in Japan, bringing with them knowledge of the outside world, of Chinese classics, Buddhism, calligraphy, and spoken Chinese (Fogel 2009, 32-45; Jansen 1992; Tokuda 2004). Best known today is the Confucian scholar Zhu Shunshui (1600-1682, Jp. Shu Shunsui), who settled in Nagasaki in 1659, and in 1665 was invited by Tokugawa Mitsukuni (1628-1700), daimyo of the Mito domain and grandson of the founding shogun Ieyasu, to live under his patronage in Edo. Shunshui had dealings 
with the Confucian scholars Yamaga Sokō (1622-85) and Kinoshita Jun'an (1621-98), and went on to influence the Mito school of historical studies (Ching 1975; Ishihara 1961; Tokuda 2004, 24-102). However, dozens of other Ming exiles lived in Japan during the seventeenth and early eighteenth centuries. Many of their stories are yet to be explored in detail. A study by Tsuji, which mentions only those he considered the most significant, lists forty-three such individuals (Tsuji 1930, 660-80).

Unlike Chinese monks and scholars, who were often able to gain permission to travel elsewhere within Japan, Chinese merchants were for the most part confined to the port cities, mainly Nagasaki, where they were required to live in the Chinese quarter from 1689 onwards (Yamamoto 1983). They were served by the hereditary Japanese families of interpreters, many of whom had intermarried with Chinese families, and whose trade it was to learn spoken Chinese in order to assist with the smooth running of Nagasaki commerce. The European traders of the Dutch East India Company were also present, served in turn by hereditary Japanese families of Dutch language interpreters. Nagasaki became a center of cultural exchange where goods and ideas flowed into Japan. Attracted by this environment, hundreds of Japanese scholars and wealthy dilettantes came to Nagasaki in the hopes of acquiring books, medicines, foreign novelty items, and Chinese or Dutch language skills (Hiramatsu 1999).

Conversely, ambitious young men from interpreter families left Nagasaki to seek their fortune as Chinese teachers and calligraphers in larger urban centers like Kyoto and Edo. The role of the interpreter Okajima Kanzan (1675-1728) in the vernacular Chinese studies of Sorai's academy after Sorai left Yanagisawa employ is a well-known example (Pastreich 2011, 87-119). Kanzan is known today for having compiled the first Japanese dictionary of vernacular Chinese, Tōwa san'yō (Spoken Chinese digest, 1716) (Okumura 2007, 23-62), and like Sorai features prominently in the story of vernacular Chinese in Tokugawa Japan.

An interpreter who is less well known but who played an important role in the Yanagisawa salon while Sorai was a member is Kuraoka Bunjirō (1679-1750), the person alluded to by Sakata (see also Ishizaki 1940, 50). According to Ken'en zatsuwa, the account of Sorai's circle compiled after he left Yanagisawa employ, Kuraoka was "of extremely strange countenance. He spoke Chinese well and was possibly the son of a Nagasaki interpreter or possibly the illegitimate child of someone from China" (Ken'en zatsuwa 1979, 4:82). After arriving in Edo from Nagasaki in 1698, aged nineteen, and having frightened with his strange appearance the merchant household to whom he presented a letter of introduction, Kuraoka won their confidence with his exemplary calligraphic skills and eventually came to the attention of Sorai, who brought him to work in the Yanagisawa household. Despite his non-samurai background, Kuraoka came to play an important role in demonstrations of the Chinese language abilities of the Yanagisawa salon, delivering a spoken Chinese lecture on the Confucian classic Daxue (The Great Learning) on the occasion of one shogunal visit (Tokugawa jikki 1976, 501) and participating in a spoken Chinese discourse on Zhongyong (The Doctrine of the Mean) on another (SHJ 1915, 29:47v). The calligraphy on Sorai's tombstone is said to be by Kuraoka (Ken'en zatsuwa 1979, 82).

Ishizaki and Lidin have also noted that Nakano Giken (1666-1720), a former Nagasaki Chinese interpreter who taught spoken Chinese in the household of another powerful daimyo, Makino Narisada (1634-1712), was influential in the Chinese language 
studies of the Yanagisawa circle through Yanagisawa connections to Makino, and that Giken taught spoken Chinese to Sorai (Ishizaki 1940, 50-51; Lidin 2011, 11). However, it was Kuraoka who was the interpreter employed in the Yanagisawa household itself, and who is named in the Yanagisawa records as the person performing Chinese lectures during shogunal visits. Kuraoka also seems to have been preferred as a Chinese speaker over the now more famous Okajima Kazan, who, by the time Kuraoka joined the Yanagisawa salon, was already associated with Yoshiyasu (Ishizaki 1940, 50), but who does not appear in the records of those who participated in the public performance of Chinese in Yoshiyasu's household, discussed below.

\section{ŌBaKu Buddhism In JaPan}

Another group of Chinese speakers in Japan was to be particularly significant for Yanagisawa Yoshiyasu: Ōbaku monks. Ōbaku (Ch. Huangbo) Buddhism, though not formally recognized as a separate sect until 1876, traces its origins in Japan to the arrival of the Chinese monk Yinyuan Longqi (1592-1673), who presided over a community of Chinese and Japanese monks at the Kōfukuji Temple in Nagasaki starting in 1654 (Baroni 2000; Kimura 2005, 2007; Wu 2014a). By the middle of the seventeenth century, it had become common practice for Chinese lay believers and monks in Nagasaki to invite Chinese monks to serve as abbots in their temples. Yinyuan was the most prominent abbot to serve in Nagasaki, and numerous Japanese monks and laymen came to hear his teaching, which spread from Nagasaki to other parts of Japan. Yinyuan was from the Wanfu temple (Jp. Manpukuji) on Mount Huangbo in Fujian Province, and taught a version of Linji (Jp. Rinzai) Zen Buddhism that incorporated the practice of chanting the name of Amida Buddha, which was usually associated with Pure Land rather than Zen sects. Although rivalries emerged later, Japanese Rinzai monks were initially welcoming of Yinyuan and petitioned senior shogunate officials to allow him to travel to Kyoto and teach at the Rinzai-affiliated Myōshinji temple. The shogunate granted Yinyuan permission to travel to Kyoto and remain under what amounted to house arrest there. He was later permitted to travel to Edo and pay his respects to the shogun, an event that went so well that Yinyuan was granted land and permission to found his own temple. Öbakusan Manpukuji was founded in Uji near Kyoto in 1661.

As Helen Baroni has noted, Yinyuan's early success with the secular authorities was to characterize Ōbaku's position throughout the Tokugawa period (Baroni 2000, 165-92). Taking advantage of new regulations in 1665 that allowed branch temples to decide their own affiliation, between 1665 and 1745 the number of Ōbaku temples grew to over one thousand, at a time when Buddhism was strictly controlled and the founding of new temples prohibited (Baroni 2000, 186-88). ${ }^{2}$ This total number of temples did not make Ōbaku a large Buddhist sect within Japan by the standards of the time; by way of comparison, a record of branch temples belonging to the longer-established

${ }^{2}$ Three records (matsujicho $)$ of Ōbaku branch temples are extant from the Tokugawa period, complied in 1745, 1771, and 1843. They survive in the Bunkaden library at Ōbakusan Manpukuji in Kyoto, and their contents are reproduced in modern characters in Takenuki (1990). The 1745 record lists 1,043 temples. 
Sōtō sect compiled in 1745 lists 17,574 temples (Kagashima 1980, 5-10). However Ōbaku punched above its weight. Senior shogunate officials not only allowed the founding and spread of Ōbaku temples, they sponsored the procurement of Chinese abbots for Manpukuji. Between 1661, when Manpukuji was founded, and 1784, when the last Chinese Ōbaku monk in Japan died, all but four of the twenty-one abbots of Manpukuji were Chinese and (with the exception of Yinyuan) had been invited from the continent to Japan by the shogunate for that purpose. It was only after unsuccessful attempts to procure Chinese monks to replace the last abbot in 1784 that it became the norm for Manpukuji abbots to be of Japanese origin (Wu 2014a, 209-42). In addition to the abbots of Manpukuji, numerous other Chinese Ōbaku monks were permitted to travel within Japan and to teach in temples across the country. Between 1654 when Yinyuan arrived and 1784 when Dacheng Zhaohan (Jp. Daijō Shōkan, 1709-84), the last Chinese abbot of Manpukuji, died, over eighty Chinese Ōbaku monks visited or lived in Japan with the permission of the shogunate (Kimura 2005). These Chinese monks, and the relative freedom of movement they enjoyed, are at odds with the traditional characterization of Tokugawa Japan as isolated from foreign contact. Far from keeping Ōbaku monks at bay or safely in Nagasaki, serving only the Chinese community there, the shogunate and some of its highest officials, including Yoshiyasu, actively sought their company.

\section{Yanagisawa Yoshiyasu's Study of ZeN}

Yoshiyasu first became interested in Zen Buddhism at age twenty when he began visiting Rinzai Zen monks at the Ryūkōji and other temples in Edo in 1677 (Tsuji 1947, 230). Initially, the monks with whom he had contact were Japanese-Tetsugyū Dōki (1626-1700) and Hōun Myōdō (1638-1706)—and so the question of Chinese fluency did not arise (Ōtsuki, Katō, and Hayashi 1988, 362-63). However, Yoshiyasu reached a turning point in 1692 when he met Gaoquan Xingdun (Jp. Kōsen Shōton, 1633-95), the fifth abbot of Manpukuji, who was in Edo offering official thanks to the shogun for his appointment (Miyakawa 2007, 202; Ōtsuki et al. 1988, 362). Yoshiyasu remained in contact by letter with Gaoquan, received him on his periodic visits to Edo, and in 1695 formally became his disciple.

Although Yoshiyasu remained in contact with Japanese monks, after becoming Gaoquan's disciple he was to have a special affinity with the Chinese abbots of Manpukuji. As appendix 1 shows, Yoshiyasu personally met with each successive Manpukuji abbot during their periodic visits to Edo and remained in contact with them when they returned to Uji. It was likewise to the Chinese abbots that Yoshiyasu turned for his most important ceremonial needs, particularly Yuefeng Daozhang, the monk whose Chinese lecture Yoshiyasu is said to have understood. At Yoshiyasu's request, Yuefeng founded the Eikeiji, Yoshiyasu's mortuary temple (bodaiji) in Kai, in 1708 (Tsuji 1947, 254); and after the death of Tsunayoshi in 1709, Yoshiyasu took Buddhist orders together with his principal wife, Soshi Sadako (1661-1713), in a ceremony conducted by Yuefeng.

The importance of Ōbaku Buddhism in Yoshiyasu's life is further underscored by the detailed records that were kept of his written correspondence with Buddhist monks, most of whom belonged to the Ōbaku lineage and many of whom were Chinese. As noted in 
appendix 1, some of these letters and poems are contained in the official record of Yoshiyasu's household, Rakushidō nenroku, or preserved in the collections of Manpukuji and affiliated Ōbaku temples. Upon the death of Iizuka Someko (1665-1705), one of Yoshiyasu's concubines who had been his companion in Zen studies, a more comprehensive collection was compiled from Yoshiyasu's personal archive and presented to Someko's mortuary temple, the Ryūkōji in Edo. This collection, Chokushi gohō jōō roku (Record of eternal answers on protecting the dharma, with imperial preface, 1705), with a preface by Retired Emperor Reigen (1654-1732), is a thirty-three-fascicle annotated record of the questions Yoshiyasu asked in his search for understanding, and the answers he received from his Zen teachers. Koshiroku (Record of old paper, undated), a work by Someko, which details her own search for enlightenment, is appended to the collection (Nakao 1973).

\section{How Did Yoshiyasu Communicate with Chinese Monks?}

Yoshiyasu first encountered the sounds of spoken Chinese in 1692 when he held a reception for Gaoquan Xingdun, the first of the Manpukuji abbots to become his teacher. Matsukage nikki records that Yoshiyasu could not understand what he was hearing but "found it attractive for the feeling of China that it conveyed" (karameki okashiū miyu, Miyakawa 2007, 202). Clearly, on this occasion Yoshiyasu was using interpreters. He did so again in 1696 when he met the sixth abbot of Manpukuji, Qiandai Xing'an. On this latter occasion, Matsukage nikki records in detail the amusing impression the interpreters made:

As usual there was conversation giving off an air of Chineseness (karamekitaru onmonogatari). The interpreters have traveled between our land and that one and could make themselves well understood, but spoke to each other in incomprehensible mumblings. Naturally one would have been able to understand what they said to our side, but when they turned to the other side and produced strange sounds it must have sounded very odd to those who happened to be seated out of the way and couldn't see what was going on. I expect the flighty young attendants, in particular, must have burst out laughing. (Miyakawa $2007,260-61)^{3}$

On both these occasions, and most likely on the other occasions when he had an audience with Chinese monks, Yoshiyasu was exposed to the sounds of spoken Chinese paired with a Japanese translation. As detailed in appendix 1, he met with the Chinese abbots of Manpukuji or with Chinese monks representing them on at least twelve occasions over a period of sixteen years. Yoshiyasu's closest relationship was with Yuefeng Daozhang. At the time Yuefeng gave the lecture for Tsunayoshi that Yoshiyasu is said to have understood, Yuefeng was in fact staying as Yoshiyasu's guest at his suburban estate

${ }^{3}$ Ōgimachi Machiko, the author of Matsukage nikki, would not have been present on this occasion, as she had given birth to her second son by Yoshiyasu only a week earlier and must have relied on other records or the memory of people who had attended (Gaye Rowley, personal communication). 
(shimoyashiki), the Rikugien. Yuefeng remained at the Rikugien for approximately five weeks and had numerous audiences with Yoshiyasu during that time.

Yoshiyasu would therefore have been well used to hearing spoken Chinese by the time he attended Yuefeng's shogunal audience in 1708, and may even have acquired some Chan (Jp. Zen) Buddhist vocabulary. He certainly would have been familiar with the contents of Yuefeng's teaching, having studied Ōbaku under Chinese monks for sixteen years by that stage and having spent a considerable amount of time communicating with Yuefeng. However, it is unlikely that Yoshiyasu could have acquired any meaningful degree of speaking fluency in Chinese from these meetings alone.

Matsukage nikki records that Yoshiyasu was still using "brush talk" during his audiences with Yuefeng in 1708, twelve years after his first encounter with Yuefeng's predecessor, Gaoquan: "Even though [Yuefeng] is from China and one cannot exchange speech with him, they exhaustively discussed what was deep in their hearts by exchange of writing... They also composed Chinese poems" (Miyakawa 2007, 927). "Brush talk" (hitsugo or hitsudan) involved communicating in writing using Sinitic, the logographic, written lingua franca of East Asia. Literary Sinitic (also known as "classical Chinese" or "literary Chinese," and in Japan as kanbun) was understood by means of established, region-specific reading traditions, which associated Chinese logographs with local words, and provided methods of syntactical arrangement that enabled the conversion of Chinese syntax to local ones. Brush talk in literary Sinitic had long been a feature of diplomatic communication in face-to-face meetings between Japanese and Chinese speakers, because each could read the Chinese writing system according to their own traditions. As in the above example, Chinese-style poetry was also an important feature of such encounters, made possible by the Chinese logographic writing system and a shared storehouse of classical allusion from which the educated men of East Asia could draw (Murai 2009). Yoshiyasu may have been using brush talk in order to display his abilities and education as a poet rather than because he could not converse with Yuefeng in speech. However, no spoken conversations between the pair were preserved or noted in the records.

Yoshiyasu regularly used brush talk in his meetings with Chinese monks and preserved records of these conversations and poetic exchanges, some of which were incorporated in Chokushi gohō jōō roku, the official record of Yoshiyasu's Zen studies mentioned above. Yoshiyasu also had calligraphic copies of some brush talk discussions and poetic exchanges made and presented to the Ōbaku Manpukuji temple in Uji (Lidin 2011, 7-9; Tsuji 1947, 251-52). For the most part, the records of Yoshiyasu's brush talk with Chinese monks show that they were written according to the conventions of literary Sinitic; he did not use vernacular Chinese on these occasions.

However, when writing to the monks when they returned to Uji, Yoshiyasu did stud his Chinese correspondence with some non-classical conventions and terminology. For example, he used the expressions shǒu q̌̌ (Jp. shukei) and shǒu jiăn (Jp. shukan) to refer to his correspondence and to indicate that he had penned his letters himself (e.g., Miyakawa 2013, 33-35). These terms are not in the most comprehensive historical dictionary of Japanese, but were current during the Ming period in China (Hanyu dacidian 2003; Nihon kokugo daijiten 2001-3). Although shǒu qř is attested to in the writings of the Song dynasty literatus Su Shi (1037-1101) (Morohashi 1984-86), it is most likely that Yoshiyasu began using these terms as a result of his contact with the Chinese monks 
to whom his letters were addressed. This may be what Ōgimachi Machiko refers to in Matsukage nikki when she describes Yoshiyasu's Chinese correspondence as "Chinesestyle letters" (Miyakawa 2007, 910). The expression "Chinese-style letters" (karayo no fumi) has a different nuance than the term Machiko usually uses to describe literary Sinitic (mana) (Miyakawa 2007, 261, 709, 828). It is probable that in the course of his exchanges with Chinese monks, Yoshiyasu picked up certain contemporary Chinese vocabulary items, and that "Chinese-style letters" refers to this stylistic choice. Machiko's record was an account intended to reflect the glory of the Yanagisawa house, and was put together from information gleaned from various sources, probably including Yoshiyasu himself. It is therefore worth noting that this use of contemporary Chinese stylistics was considered worthy of mention.

\section{Lectures for THE SHOgUN}

Relying on these records of Yoshiyasu's dealings with Chinese monks, we can conclude that Yoshiyasu probably did have some familiarity with spoken Chinese, as a listener at least, even though it is unlikely he was a fluent speaker. In addition to this exposure to spoken Chinese through Ōbaku monks, spoken Chinese was a prominent feature of Yoshiyasu's salon. Many of his own retainers spoke Chinese and performed public lectures on the Chinese classics using Chinese when the shogun Tsunayoshi made official visits. Tsunayoshi placed importance on Confucian teaching as a source of moral inspiration for his officials and ordered that Confucian lectures and debates be held on a regular basis throughout his rule (Bodart-Bailey 2006, 215-38). The lectures Yoshiyasu hosted, however, are distinguished by the fact that they were given in vernacular Chinese. On one occasion, Yoshiyasu had the lecture recorded, complete with glossed phonetic guides to the spoken Chinese pronunciation, in his household record, Rakushidō nenroku.

There are at least three recorded occasions on which vernacular Chinese lectures were performed by Yoshiyasu's retainers for the shogun (Ishizaki 1940, 49-50). ${ }^{4}$ The first, preserved in the annals of the Tokugawa house (Tokugawa jikki) was on the fifth day of the first month of 1703 when Tsunayoshi made one of his many visits to the Yanagisawa mansion. Among the lavish entertainments provided for Tsunayoshi was a dialogue in Chinese (tōon) performed by Yanagisawa retainers (Tokugawa jikki 1976, 738-39). The Tokugawa jikki reports this occasion as part of a long list of the kinds of entertainment that usually accompanied the visits that Tsunayoshi made to the houses of his retainers, "including Makino Narisada, governor of Bingo, and Matsudaira Yoshiyasu, governor of Minō, but particularly Yoshiyasu” (Tokugawa jikki 1976, 738). As mentioned above, Narisada employed the Nagasaki interpreter of Chinese, Nakano Giken, in his household. With the exception of 1705 when Giken was based in Kyoto, he worked for Narisada from 1684 until Giken's death in 1720 (Ishizaki 1940, 51). Yoshiyasu, who employed the interpreter Kuraoka Bunjirō after Narisada had hired Giken, may well have been following Narisada’s lead.

Both the Tokugawa jikki and Rakushidō nenroku then record that on the thirteenth day of the month following the first of the Yoshiyasu lectures, Tsunayoshi visited the

\footnotetext{
${ }^{4}$ Note that the Tokugawa jikki index records no other instances.
} 
Yanagisawa mansion again, where Kuraoka Bunjirō lectured on the Daxue in spoken Chinese, with Ogyū Sorai performing the role of translator (tsūji). This was followed by a spoken Chinese dialogue (SHJ 1915, 22:15r-21v; Tokugawa jikki 1976, 501). Clearly, Tsunayoshi's official visits were a source of great pride for Yoshiyasu, demonstrating how far he had come in the world, and Rakushido nenroku records numerous visits in lavish detail, down to the gifts exchanged and the works of art that were used to decorate the reception areas.

The third record of a Chinese lecture performed for Tsunayoshi does not appear in the Tokugawa jikki but is preserved in Rakushido nenroku: on the fifth day of the second month of 1705, thirteen of Yoshiyasu's retainers, including Ogyū Sorai and Kuraoka Bunjirō, discoursed on the Confucian classic Zhongyong (The Doctrine of the Mean), and Yoshiyasu had the discussion recorded with glossed pronunciation guides indicating the sounds of Chinese (SHJ 1915, 29:40r-51v, 52r-58v; SHJ 1919, 38:5v-14v). The fact that neither the Tokugawa jikki nor Rakushidō nenroku are exhaustive in recording each of the occasions on which spoken Chinese lectures were performed for the entertainment of the shogun suggests there were probably more instances than the three noted here.

As for exactly what variety of spoken Chinese was used on these occasions, there is insufficient evidence from which to draw firm conclusions. Of the three recorded occasions on which lectures took place, only the transcription from the fifth day of the second month of 1705 survives. The original variety of Chinese pronunciation is obscured by the phonetics of the Japanese kana syllabary, but it is worth noting that the glosses broadly approximate the sounds of modern Mandarin (Miyakawa 2008, 226). This is not inconsistent with the probable exposure to guanhua by interpreters like Kuraoka Bunjirō. Guanhua (lit. "official speech" or "the speech of officials") was the common spoken language of administration in the Ming and Qing dynasties, which later became the basis of modern standard Chinese (putonghua). Such evidence as has survived of the way Ōbaku monks in Japan read Sinitic characters suggests they mainly used guanhua, with some elements of Fuzhou pronunciation, Fuzhou being the region in which the Chinese Huangbo (i.e., Öbaku) monastery was located (Zhang 1996). It is therefore likely that the variety or varieties of spoken Chinese used in the Yanagisawa household included guanhua, and that this was used on official occasions.

But why did Yoshiyasu and the shogun Tsunayoshi include spoken Chinese on the program for the shogun's official visits? The entertainments hosted by Yoshiyasu on such occasions were lavish displays of wealth, culture, and novelty, and so it is tempting to regard the inclusion of spoken Chinese as being for entertainment purposes. The Tokugawa jikki entry for Tsunayoshi's visit to the Yanagisawa mansion in the first month of 1703 records the types of amusements that were provided on such occasions over the years (Tokugawa jikki 1976, 738-39). With the exception of Noh dances performed by Tsunayoshi himself, Confucian lectures formed the bulk of the entertainment. However, also included over the years were displays of swordsmanship and fine-quality horses; a lecture on acupuncture by a blind medic; lectures on Japanese literature such as The tale of Genji, the Shin kokin wakashu (New collection of poems, ancient and modern, 1205), and Tsurezuregusa (Essays in idleness, c1330); as well as Zen dialogues and discussions of Pure Land Buddhism.

Thus there was undoubtedly an element of novel entertainment value in some of these choices, and scholars have tended to describe Tsunayoshi's sponsorship of 
Confucianism lectures as merely a genteel form of amusement. However, as BodartBailey (2006, 233-37) argues, Sorai considered Tsunayoshi's interest in Confucianism to be genuine, and in the case of the vernacular lectures on the Chinese classics, the fact that Yoshiyasu had the Chinese pronunciation carefully transcribed as part of the record of one such event indicates that he at least did not consider spoken Chinese simply amusing gibberish performed for novelty or shock value. The Tokugawa jikki describes the support of these various entertainments, including spoken Chinese, as a serious act of cultural patronage: "by enjoying these entertainments with each official visit, no effort was spared to preserve various arts and skills. A truly impressive state of affairs" (Tokugawa jikki 1976, 739). For Yoshiyasu, these shogunal visits were an opportunity to display his fitness for the role to which Tsunayoshi had raised him, and spoken Chinese was part of the cultural repertoire deployed to do so.

\section{Why Chinese? Imitating Tokugawa Mitsukuni}

Before reaching a final conclusion as to Yoshiyasu's Chinese abilities, it is necessary to consider several other important reasons for his patronage of spoken Chinese learning. Yoshiyasu was not alone in his patronage of Chinese individuals in Japan, and the example of Tokugawa Mitsukuni, who sheltered the Ming exile Zhu Shunshui, offers an additional clue as to why Yoshiyasu encouraged spoken Chinese in his salon. As one of the three highest-ranking branches (gosanke) of the Tokugawa family and occupying strategic lands adjacent to the shogunal capital, the heads of the Mito domain were among the most powerful daimyo during the Tokugawa period, and were expected to provide shogunal heirs if the reigning shogun had no children of his own. Although Mito was smaller and not as rich as the domains occupied by the other two branches, it was closer to Edo and of all the daimyo the lord of Mito alone was permitted to reside permanently in Edo, giving rise to the popular notion that he was the "viceshogun" (tenka no fuku shōgun) (Koschmann 1987, 2). Yoshiyasu had risen from humble origins to receive honors that mirrored the familial and geographical status of the gosanke, particularly the Mito daimyo: associated with the shogun in the public mind, Yoshiyasu held a large domain that had previously only been occupied by members of the Tokugawa house, and had the right to use the surname of the Tokugawa household as if he were a family member.

It is not surprising then, that Yoshiyasu, being of lower-ranking origins and lacking appropriate household traditions of his own, should look to the Mito daimyo as a model. The Mito school of thought was one of the most influential during the Tokugawa period, and Tokugawa Mitsukuni in particular was known for his encouragement of Confucian and native scholarship (Suzuki 1987). Even more significant, though not as widely known, is that spoken Chinese played a role in Mito learning on Mitsukuni's watch, and that the Ming exile Shunshui, when teaching Confucian scholars in Mito employ, did so using spoken Chinese. The work of Tokuda Takeshi has revealed that Asaka Tanpaku (1656-1737), an early leader of the Mito school, was one scholar who learned to intone various Chinese classics using contemporary Chinese pronunciation, and that notes survive that indicate that Mito scholars studied vernacular Chinese vocabulary with Shunshui (Tokuda 2012, 29-53). There is a striking similarity between Yoshiyasu’s 
encouragement of spoken Chinese learning among his retainers and this earlier example of Mitsukuni's own intellectual circles, which suggests Yoshiyasu may have been inspired by Mitsukuni to deploy spoken Chinese as a way of indicating his fitness for the position to which the shogun had raised him.

Unlike Yoshiyasu, Mitsukuni is often characterized as anti-Buddhist because of his order to separate Buddhist temples from kami worship (e.g., Suzuki 1987, 158-65). However, Mitsukuni's ruling was motivated as much by the desire to preserve the purity of Buddhist doctrine as it was to suppress it, and he continued to patronize Buddhist monks and temples. Significantly, after Shunshui died, Mitsukuni maintained his links with Ming supporters in exile by employing the Chinese monk Donggao Xinyue (Jp. Tōkō Shin'etsu, 1639-95) to work in the Tentokuji temple in Mitsukuni’s domain (Shyu 2008). Donggao was a Sōtō sect monk formerly from a temple at the West Lake near Hangzhou, and was a talented artist and player of the zither (qin). He came to Japan at the invitation of the Chinese Ōbaku monk Chengyi Daoliang (Jp. Chin’i Dōryō) in 1676. Although Yoshiyasu was to have even closer ties with Chinese monks than Mitsukuni, his patronage of the highly cultured, native Chinese speaking Ōbaku abbots mirrors Mitsukuni's earlier treatment of Donggao.

Both Donggao and Shunshui were exiles from the Ming dynasty, and their presence in Japan reinforced the notion, held by some at the time (Nakai 1980, 174-81), that with China under the control of the Qing "barbarians," who were Manchus and not of Han Chinese ethnicity, Japan was the legitimate inheritor of a cultural traditions associated with "China" and the Sinitic classics. This view was apparently shared by Shunshui himself. In a letter sent to the continent, he wrote:

People of the world always say that the ancients were superior to modern men, that China is better than other countries. This is due to their myopia.... But should such a lord [as Tokugawa Mitsukuni] be living in China and have the assistance of famous and worthy men, he would have no difficulty in bringing about a society of harmony and peace. (translated in Ching 1975, 186)

Japan, and Mitsukuni in particular, afforded Shunshui a haven where he could live as a Confucian scholar according to the dictates of his conscience. In return, his presence spoke of the extent of Japanese civilization and its appropriateness as a refuge for men of Confucian virtue.

Clearly, the religious aspects of Ōbaku were important to Yoshiyasu, but his choice of this particular type of Zen Buddhism, and the Chinese abbots of Manpukuji in particular over local options, lies in Ōbaku's continental origins and the cultural accomplishments of its monks, much like Tokugawa Mitsukuni’s interest in Zhu Shunshui. Wu Jiang (2014a) has argued that for Japanese rulers in the seventeenth and eighteenth centuries, Ōbaku monks, who came from the Chinese mainland and provided a direct link to Buddhist temples there, were a powerful source of authority at a time when scholars in East Asia were attempting to redefine intellectual, religious, and philosophical authenticity in the wake of the Ming collapse. This was undoubtedly true of Yoshiyasu; the Manpukuji abbots were highly educated men who by their talents and social status added to the prestige of his circle. In Matsukage nikki, Ōgimachi Machiko records the refined impression left by Yuefeng on one of his visits to Yoshiyasu: 
This holy man is from China, or more specifically, from a place called West Lake. His birthplace is near the ancient capital, retaining traces of it and by no means common. Since it is a region where people have pure hearts, and among them he has a noble mind and character, he is a holy man particularly sincere in following the Buddha's path. (Miyakawa 2007, 910)

Not only is Yuefeng described as a holy man but he comes from West Lake (Xihu), near Hangzhou, the former capital of the Southern Song dynasty. The words used to describe him and his hometown suggest refinement and aristocratic bearing: "not common" (iyashikarazu), and "noble" (atehaka). Moreover, Machiko, the author of Matsukage nikki, later reports that Yuefeng compared the garden at Yoshiyasu's suburban estate, the Rikugien, to his hometown of West Lake (Miyakawa 2007, 1071), an area famous for its scenery, thus imparting to Yoshiyasu the reflected glory of Chinese civilization. ${ }^{5}$ Kōrakuen, Tokugawa Mitsukuni’s own garden in Komagome near where Yoshiyasu built the Rikugien, contained a miniature version of West Lake. Kōrakuen had been started by Mitsukuni's father Yorifusa, but was completed by Mitsukuni with the help of Zhu Shunshui (Ching 1975, 190). Such Chinese details were part of the visible cultural trappings of power in Japan, and contact with the abbots of Manpukuji was an opportunity to reinforce the idea that rulers like Yoshiyasu, far from being peripheral barbarians, preserved the cultural traditions of the sinographic (but no longer exclusively Chinese) world.

The interest in Ōbaku Buddhism displayed by the shogun Tsunayoshi likewise reinforced Japan's role as inheritor of the cultural traditions associated with sinographic writing, but increasingly, no longer with the Chinese mainland. As detailed in appendix 1, Manpukuji's Chinese abbots were required to make periodic trips to Edo to offer thanks to the shogun for their appointment to office or for the bestowal of honors such as the right to wear the Purple Robe (shie), which was a recognition of seniority awarded to abbots of certain major temples (see Williams 2009). Wu argues that these visits are evidence of the shogunate treating Manpukujis Chinese abbots in a manner comparable to Korean and Ryukuan embassies, suggesting that the founding of Manpukuji and the symbolic use of Chinese monks may have been calculated measures intended to co-opt China into a Japan-centered world order in the absence of formal diplomatic ties with the Qing court (Wu 2014b; see also Toby 1991, 53-109). Something similar was surely at work in Yoshiyasu's patronage of the Chinese abbots of Manpukuji.

\section{Conclusion}

So in the end what can be said of Yoshiyasu's Chinese abilities? We do not have evidence that he systematically studied the spoken language with a teacher, although he may possibly have done so. What we do know for certain, however, is that Yoshiyasu was exposed to spoken Chinese (probably guanhua with elements of Fuzhou pronunciation) on a regular basis over a fifteen-year period prior to his reported ability to understand Yuefeng's teaching at the shogunal castle in 1708, and that he had the pronunciation carefully recorded on at least one occasion and used current, non-classical Chinese

\footnotetext{
${ }^{5}$ On the Rikugien, see Miyakawa (2012, 485-510).
} 
expressions in his letters. By the time of Yuefeng's shogunal audience, Yoshiyasu would also have had a good grasp of Yuefeng's Buddhist teaching, as evidenced by the extensive records of his meetings with Ōbaku monks and his correspondence with them on religious matters, particularly Yuefeng, who stayed with Yoshiyasu for five weeks during which period the dialogue at the shogunal castle took place. It is therefore likely that Yoshiyasu was indeed able to understand "the gist" of what Yuefeng was saying, as Sakata suggested, because of a degree of Chinese listening ability and familiarity with the probable lecture contents.

The lack of other evidence suggests that the ability to speak Chinese was not part of Yoshiyasu's repertoire. He was keen to encourage the speaking of Chinese among his retainers, however, a division of labor that mirrors contemporary attitudes toward oral interpreting as a low-status activity. At the Chinese court, the learning of foreign languages had long been delegated to lower-ranked functionaries known as "tongue men" (sheren) who were trained to deal with the languages of the "barbarians" (yi) on the periphery of China (Cheung 2006, 36). Likewise, in Japan, learning to speak foreign languages was outsourced to hereditary families of interpreters based in the port cities who, while indispensable, were often denigrated by contemporary scholars for their lack of a proper education (Pastreich 2011, 94-95; Sugimoto 1990, 72-76). ${ }^{6}$ By the seventeenth century, with spoken Chinese ability on the wane among the Korean ruling class (Wang 2014) and not a feature among Japanese elites beyond monastic circles, diplomatic missions between the two nations relied on interpreters to facilitate discussions between high-ranking officials. However, when high-ranking officials in such missions wished to communicate directly with their hosts on a matter of importance, they dispensed with interpreters and used Sinitic "brush talk," as did Yoshiyasu and his monastic friends. No doubt this was in part to preserve a record of important discussions, but it also suggests that someone of Yoshiyasu's rank may have felt it ill befitting his status to act as his own interpreter-he had Nagasaki linguists and house scholars for that. Likewise, the records show daimyo like Mitsukuni and Narisada, and the shogun Tsunayoshi, ordering or sponsoring the speaking of Chinese, rather than speaking it themselves.

And why was the sponsorship of spoken Chinese considered significant by these members of Japan's warrior elite, when the written language had held and continued to hold such prestige? To the quest for religious and philosophical "authenticity" afforded by contact with Ming exiles, there was an indispensable linguistic dimension. For Yoshiyasu, Tsunayoshi, Mitsukuni, and Narisada, spoken Chinese was a communication tool that, together with traditional methods like "brush talk," was used to maintain links with monks and secular scholars from the continent, particularly those associated with the Chinese intellectual and religious heritage that traced its lineage via the Ming rather than Qing dynasty. This explains their interest in contemporary spoken Chinese, despite the long-privileged position of written literary Sinitic. The links afforded by spoken Chinese signaled that Japanese warrior elites were the protectors and inheritors of the Sinitic cultural heritage in the wake of the Ming collapse. Prior to the scholarly interest in vernacular Chinese and the popularity of Ming and Qing literature in Japan from the Kyōhō period onwards, Chinese orality thus functioned as a sign of their fitness for power in Japan and the East Asian world.

${ }^{6}$ For a Korean example, see Wang $(2014,76-83)$. 


\section{Acknowledgments}

I would like to thank professors Gaye Rowley and Miyakawa Yōko for their advice on materials relating to the Yanagisawa house, and the anonymous JAS reviewers for comments on the paper that informed its revision. I would also like to express my gratitude to Ven. Kimura Tokugen and Ven. Tanaka Chisei for assisting me with access to the Ōbaku archives.

\section{List of References}

Baroni, Helen Josephine. 2000. Öbaku Zen: The Emergence of the Third Sect of Zen in Tokugawa Japan. Honolulu: University of Hawai'i Press.

Bodart-Bailey, Beatrice. 1979. "Councillor Defended: Matsukage Nikki and Yanagisawa Yoshiyasu.” Monumenta Nipponica 34(4):467-78.

2006. The Dog Shogun: The Personality and Policies of Tokugawa Tsunayoshi. Honolulu: University of Hawai i Press.

Cheung, Martha. 2006. An Anthology of Chinese Discourse on Translation: From Earliest Times to the Buddhist Project. Vol. 1. Manchester, UK: St. Jerome Publishing.

Ching, Julia. 1975. "Chu Shun-Shui, 1600-82. A Chinese Confucian Scholar in Tokugawa Japan.” Monumenta Nipponica 30(2):177-91.

Fogel, Joshua A. 2009. Articulating the Sinosphere: Sino-Japanese Relations in Space and Time. Cambridge, Mass.: Harvard University Press.

Funutome MAKi 福留真紀. 2011. Shōgun sokkin Yanagisawa Yoshiyasu: Ikanishite akumei wa tsukurareta $k a$ 将軍側近柳沢吉保：いかにして悪名は作られたか [The shogun’s close associate, Yanagisawa Yoshiyasu: How did he get a bad name?]. Tokyo: Shinchōsha.

HANYU DACIDIAN 漢語大詞典 [Comprehensive Chinese DiCTIONARY]. 2003. Shanghai: Hanyu dacidian chubanshe.

Hayashi YaWARA 林和. 1921. Yanagisawa Yoshiyasu 柳沢吉保. Tokyo: Jitsugyō no Nihonsha.

Hedberg, William. 2012. "Locating China in Time and Space: Engagement with Chinese Vernacular Fiction in Eighteenth-Century Japan.” PhD diss., Harvard University.

HiRAmatsu KanjI 平松勘治. 1999. Nagasaki yūgakusha jiten 長崎遊学者事典 [Dictionary of scholar-visitors to Nagasaki]. Hiroshima: Keisuisha.

IMANAKA KANJI 今中寛司. 1966. Sorai gaku no kisoteki kenkyū 徂徠学の基礎的研究 [Foundational research on the teachings of Ogyū Sorai]. Tokyo: Yoshikawa kōbunkan.

Ishinara Michiniro 石原道博. 1961. Shu Shunsui 朱舜水. Tokyo: Yoshikawa kōbunkan.

IsHIZAKI MATAZO 石崎又造. 1940. Kinsei Nihon ni okeru Shina zokugo bungakushi 近世日本 に於ける支那俗語文学史 [A history of vernacular Chinese literature in early modern Japan]. Tokyo: Kōbundō shobō.

Jansen, Marius B. 1992. China in the Tokugawa World. Cambridge, Mass.: Harvard University Press.

Jōo, Fumiko. 2011. “The Peony Lantern’ and Fantastic Tales in Late Imperial China and Tokugawa Japan: Local History, Religion, and Gender.” PhD diss., University of Chicago.

Kagashima Sōjun 鏡島, 宗純. 1980. Enkyōdo Sōtōshū jiin honmatsuchō 延享度曹洞宗寺院本 末牌 [Record of Sōtō sect temples in the Enkyō era]. Tokyo: Meicho fukyūkai. 
Ken'En ZatsuWa 滴園雜話 [Miscellaneous tales of Ken'en (Ogyū Sorai)]. 1979. In Zoku Nihon zuihitsu taisei 続日本随筆大成 [Further collection of Japanese essays], 4:63-108. Tokyo: Yoshikawa kōbunkan.

Kimura TokUgen 木村得玄. 2005. Ōbakushū no rekishi, jinbutsu, bunka 黄檗宗の歴史 • 人物・文化 [The history, people, and culture of the Ōbaku sect]. Tokyo: Shunjūsha. —. 2007. Shoki Ōbakuha no sōtachi [Early Ōbaku monks]. Tokyo: Shunjūsha.

KOKUSHO JINMEI JITEN 国書人名辞典 [DiCTIONARY OF NAMES IN JAPANESE BIBLIOGRAPHY]. 1995.

Vol. 2. Tokyo: Iwanami shoten.

Koschmann, J. Victor. 1987. The Mito Ideology: Discourse, Reform, and Insurrection in Late Tokugawa Japan, 1790-1864. Berkeley: University of California Press.

Lidin, Olof G. 1973. The Life of Ogyū Sorai: A Tokugawa Confucian Philosopher. Lund: Studentlitterature.

. 2011. "Vernacular Chinese in Tokugawa Japan: The Inquiries of Ogyū Sorai." Japonica Humboldtiana 14:5-36.

MARUYAMA MASAO 丸山真男. 1952. Nihon seiji shisōshi kenkyū 日本政治思想史研究 [Studies in the intellectual history of Tokugawa Japan]. Tokyo: Tōkyō daigaku shuppankai.

Masubuchi Katsuichi 増淵勝一. 1999. Yanagisawa Yoshiyasu sokushitsu no nikki: Matsukage nikki 柳沢吉保側室の日記：松蔭日記 [The diary of Yanagisawa Yoshiyasu's concubine: In the shelter of the pine]. Ryūgasaki: Kokken shuppan.

MiYAKAWA YōKO 宮川葉子. 2007. Matsukage nikki (Yanagisawake no kotengaku, jō) 松蔭日記 (柳沢家の古典学. 上) [In the shelter of the pine (Classical literature studies in the Yanagisawa house, vol. 1)]. Tokyo: Shintensha.

. 2008. “(Kenkyū nōto) Sanbyakunen mae no Chūgokugo: Rakushidō nenroku hōei ni nen nigatsu itsuka no kiji o megutte” (研究ノート) 三百年前の中国語:「楽只堂年録」宝 永二年二月五日の記事をめぐって [(Research note) Chinese from three hundred years ago: On the entry in Rakushidō nenroku from the fifth day of the second month of the second year of Hōei]. Kokusai keiei bunka kenkyū 国際経営 - 文化研究 13(1): 226-34.

- 2011. Rakushidō nenroku, dai ichi 楽只堂年録 第一 [Annual record of the Hall of Enjoyment, vol. 1]. Tokyo: Yagi shoten.

. 2012. Bungei no shosō to kankyō (Yanagisawake no kotengaku, ge) 文芸の諸相と環境 (柳澤家の古典学.下) [The literary and artistic environment (Classical Literature studies in the Yanagisawa house, vol. 2)]. Tokyo: Seikansha.

2013. Rakushidō nenroku, dai ni 楽只堂年録 第二 [Annual record of the Hall of Enjoyment, vol. 2]. Tokyo: Yagi shoten.

. 2014. Rakushidō nenroku, dai san 楽只堂年録 第三 [Annual record of the Hall of Enjoyment, vol. 3]. Tokyo: Yagi shoten.

Morohashi Tetsuji 諸橋嘾次. 1984-86. Daikanwa jiten 大漢和辞典 [Comprehensive Chinese-Japanese dictionary]. Tokyo: Taishūkan shoten.

Murai, Shōsuke. 2009. "Poetry in Chinese as a Diplomatic Art in Premodern East Asia." In Tools of Culture: Japan's Cultural, Intellectual, Medical, and Technological Contacts in East Asia, 1000s-1500s, eds. Andrew Edmund Goble, Kenneth R. Robinson, and Haruko Wakabayashi, 49-69. Ann Arbor, Mich.: Association for Asian Studies.

NakaI, Kate Wildman. 1980. “The Naturalization of Confucianism in Tokugawa Japan: The Problem of Sinocentrism." Harvard Journal of Asiatic Studies 40(1):157-99.

Nakamura Aya 中村綾. 2011. Nihon kinsei hakuwa shōsetsu juyō no kenkyū 日本近世白話小 説受容の研究 [Study on the reception of vernacular Chinese novels in early modern Japan]. Tokyo: Kyūko shoin. 
NAKaO Fumio 中尾文雄. 1973. Yanagisawa Yoshiyasu kō sanzenroku: Chokushi gohō jōō roku 柳沢吉保公参禅録：勅賜護法常応録 [Record of Lord Yanagisawa Yoshiyasu's Zen studies: Record of eternal answers on protecting the dharma, with imperial preface]. Shimonoseki: Eitokuji.

NIHON KOKUGO DAIJITEN 日本国語大辞典 [COMPREHENSIVE DICTIONARY OF JAPANESE]. 2001-3. Tokyo: Shōgakkan.

Ōва Osamu 大庭脩. 1967. Edo jidai ni okeru tōsen mochiwatarisho no kenkyū 江戸時代にお ける唐船持渡書の研究 [Study on books brought by Chinese boats in the Edo period]. Suita: Kansai daigaku tōzai gakujutsu kenkyūjo.

—. 1980. Edo jidai no nitchū hiwa 江戸時代の日中秘話 [Secret tales of Japan and China in the Edo period]. Tokyo: Tōhō shoten.

ОKADA KESAO 岡田袈泳男. 1991. Edo no hon'yaku kūkan: Rango tōwa goi no hyōshutsu $k i k \bar{o}$ 江戸の翻訳空間 : 蘭語・唐話語彙の表出機構 [Translational space in the Edo period: Expressive mechanisms of Dutch and vernacular Chinese vocabularies]. Tokyo: Kasama shoin.

—. 2006. Edo igengo sesshoku: Rango tōwa to kindai Nihongo 江戸異言語接触 : 蘭語・唐 話と近代日本語 [Language contact in the Edo period: Dutch, vernacular Chinese, and modern Japanese]. Tokyo: Kasama shoin.

OKUMURA KAYOKO 奥村佳代子. 2007. Edo jidai no tōwa ni kansuru kiso kenkyū 江戸時代の唐 話に関する基礎研究 [Fundamental research on vernacular Chinese in the Edo period]. Suita: Kansai daigaku.

ŌTSUki Mikio 大槻幹郎, KaTō ShōShun 加藤正俊, and HaYashi Yukimitsu 林雪光. 1988. Ōbaku bunka jinmei jiten 黄檗文化人名辞典 [Dictionary of Ōbaku people and culture]. Kyoto: Shibunkaku shuppan.

Pastreich, Emanuel. 2001. "Grappling with Chinese Writing as a Material Language: Ogyū Sorai’s Yakubunsentei.” Harvard Journal of Asiatic Studies 61(1):119-70.

—. 2011. The Observable Mundane: Vernacular Chinese and the Emergence of a Literary Discourse on Popular Narrative in Edo Japan. Seoul: Seoul University Press.

Rowley, G. G. 2010. “The Tale of Genji: Required Reading for Aristocratic Women.” In The Female as Subject: Reading and Writing in Early Modern Japan, eds. P. F. Kornicki, Mara Patessio, and G. G. Rowley, 39-58. Ann Arbor: University of Michigan Press.

Shimauchi KeIJ 島内景二. 2009. Yanagisawa Yoshiyasu to Edo no yume: Genroku runessansu no kaimaku 柳沢吉保と江戸の夢 : 元禄ルネッサンスの開幕 [Yanagisawa Yoshiyasu and the dream of Edo: The beginnings of the Genroku renaissance]. Tokyo: Kasama shoin.

SHJ (Shiryō Hensanjo 史料編纂所 [Historiographical Institute of the University of Tокүо]). 1915. 2044-144. Rakushidō nenroku 楽只堂年録 [Annual record of the Hall of Enjoyment].

—. 1919. 2044-74. Kaishōshō Yoshiyasu ason jikki 甲斐少将吉保朝臣実紀 [True account of Minister Yoshiyasu, the captain from Kai].

Shyu Shing-Ching 徐興慶. 2008. “Shin’etsu zenshi to Tokugawa Mitsukuni no shisō hensen shiron: Zhu Shunsui shisō to no hikaku ni oite” 心越禅師と徳川光图の思想変 遷試論 : 朱舜水思想との比較において [The intellectual development of the priest Shinetsu and Tokugawa Mitsukuni: In relation to the teachings of Zhu Shunshui]. Nihon kanbungaku kenkyū 日本漢文学研究 3:356-13 (31-74).

SoraI OGYū 荻生徂徠. 1977. “Yakubun sentei” 訳文鉒蹄 [A tool for translation]. In Ogyu Sorai zensh $\bar{u}$ 荻生徂徠全集 [Complete works of Ogyū Sorai], 5:15-366. Tokyo: Kawade shobō shinsha. 
Sugimoto Tsutomu 杉本つとむ. 1990. Nagasaki tsüji monogatari: Kotoba to bunka no hon'yakusha 長崎通詞ものがたり：ことばと文化の翻訳 [Tales of the Nagasaki interpreters: Translators of language and culture]. Tokyo: Sōtakusha.

SUZUKI EIICHI 鈴木暎一. 1987. Mitohan gakumon kyōikushi no kenkyū 水戸藩学問・教育史の 研究 [Study of the history of Mito thought and education]. Tokyo: Yoshikawa kōbunkan.

TAKENUKI GENSHŌ 竹貫元勝. 1990. Kinsei Ōbakushū matsujichō shūsei 近世黄檗宗末寺帳集成 [Collected temple records of the early modern Öbaku sect]. Tokyo: Yūzankaku shuppan.

Toby, Ronald P. 1991. State and Diplomacy in Early Modern Japan: Asia in the Development of the Tokugawa Bakufu. Stanford, Calif.: Stanford University Press.

TOKUDA TAKESHI 徳田武. 1987. Nihon kinsei shōsetsu to Chūgoku shōsetsu 日本近世小説と中 国小説 [Chinese novels and the early modern Japanese novel]. Musashi Murayama: Seishōdō shoten.

—. 2004. Kinsei Nitchūbunjin kōryūshi no kenkyū 近世日中文人交流史の研究 [Study of exchanges between Japanese and Chinese literati in the early modern period]. Tokyo: Kenbun shuppan.

2012. Akinari zengo no Chūgoku hakuwa shōsetsu 秋成前後の中国白話小説 [Vernacular Chinese novels around the time of Akinari]. Tokyo: Bensei shuppan.

TOKUGAWA JIKKI 徳川実紀 [True account OF the TokUgawa]. 1976. In Shintei zōho kokushi taike $i$ 新訂増補國史大系 [Revised and expanded collection of Japanese historical materials]. Vol. 43. Tokyo: Yoshikawa kōbunkan.

Tsuji ZenNosuke 辻善之助. 1930. Kaigai kōtsū shiwa 海外交通史話 [Historical accounts of foreign exchange]. Tokyo: Naigai shoseki kabushiki gaisha.

1947. Jinbutsu ronsō 人物論叢 [Collected essays on historical personalities]. Tokyo: Yūzankaku.

UENo Yōzō 上野洋三. 2004. Matsukage nikki 松蔭日記 [In the shelter of the pine]. Tokyo: Iwanami shoten.

Walthall, Anne. 2007. "Histories Official, Unofficial, and Popular: Shogunal Favorites in the Genroku Era." In Writing Histories in Japan: Texts and Their Transformations from Ancient Times through the Meiji Era, eds. James C. Baxter and Joshua A. Fogel, 175-99. Kyoto: International Research Center for Japanese Studies.

Wang, SiXIang. 2014. “The Sounds of Our Country: Interpreters, Linguistic Knowledge, and the Politics of Language in Early Chosŏn Korea." In Rethinking East Asian Languages, Vernaculars, and Literacies, 1000-1919, ed. Benjamin A. Elman, 58-95. Leiden: Brill.

Williams, David. 2009. "The Purple Robe Incident and the Formation of the Early Modern Sōtō Zen Institution." Japanese Journal of Religious Studies 36(1):27-43.

Wu, Jiang. 2014a. Leaving for the Rising Sun: Chinese Zen Master Yinyuan and the Authenticity Crisis in Early Modern East Asia. Oxford: Oxford University Press.

— 2014b. "The Taikun's Zen Master from China: Yinyuan, the Tokugawa Bakufu, and the Founding of Manpukuji in 1661.” East Asian History 38:75-96.

Yamamoto Noritsuna 山本紀綱. 1983. Nagasaki Töjin yashiki 長崎唐人屋敷 [The Nagasaki Chinese quarter]. Tokyo: Kenkōsha.

Zhang Shengyu 張 昇余. 1996. “Ōbakushū kyōten ni okeru kinsei kan’on no kōsatsu” 黄檗 宗経典に於ける近世唐音の考察 [Investigation of early modern Chinese pronunciation in sutras of the Ōbaku sect]. Ōbaku bunka 黄檗文化 116:184-45. 
Appendix 1. Yanagisawa Yoshiyasu's Contact with Chinese Ōbaku Monks.

\begin{tabular}{|c|c|c|c|}
\hline & Date & Contact & Notes \\
\hline 1692 & $\begin{array}{l}\text { 17th day of } 4 \text { th } \\
\text { month }\end{array}$ & $\begin{array}{l}\text { Fifth Manpukuji abbot Gaoquan Xingdun is in Edo } \\
\text { thanking the shogun for his appointment (Ōtsuki et al. } \\
\text { 1988, 362). Yoshiyasu invites him to his residence. After } \\
\text { their meeting, the pair exchange letters (Miyakawa } \\
\text { 2007, 202). }\end{array}$ & \\
\hline 1695 & $\begin{array}{l}5 \text { th day of } 6 \text { th } \\
\text { month }\end{array}$ & $\begin{array}{l}\text { Gaoquan is in Edo offering thanks for the Purple Robe } \\
\text { honor (Ōtsuki et al. 1988, 363). Yoshiyasu receives him } \\
\text { again, and they discuss Buddhist teaching (Miyakawa } \\
\text { 2011, 252). }\end{array}$ & $\begin{array}{l}\text { After their meeting, "many letters passed between } \\
\text { [them]" (Miyakawa 2007, 202). }\end{array}$ \\
\hline 1695 & $\begin{array}{l}\text { 8th day of } 7 \text { th } \\
\text { month }\end{array}$ & $\begin{array}{l}\text { The monk Chen Lie (dates unknown), representing } \\
\text { Gaoquan, visits Yoshiyasu, bringing a record stating that } \\
\text { Buddhist teaching has been entrusted to him, plus a } \\
\text { nyoi whisk. In response, Yoshiyasu sends } 30 \text { mai of } \\
\text { silver and other gifts (Miyakawa 2011, 255). }\end{array}$ & \\
\hline 1695 & $\begin{array}{l}\text { 15th day of } 7 \text { th } \\
\text { month }\end{array}$ & $\begin{array}{l}\text { Gaoquan is ill. Yoshiyasu inquires after his health and } \\
\text { sends medicine (Miyakawa 2011, 256). }\end{array}$ & \\
\hline 1695 & $\begin{array}{l}\text { 29th day of } 7 \text { th } \\
\text { month }\end{array}$ & $\begin{array}{l}\text { Yoshiyasu sends gifts and inquires after Gaoquan's health. } \\
\text { He has a collection of his correspondence with Gao- } \\
\text { quan collated as an appendix to the 7th month of } \\
\text { Rakushido nenroku (Miyakawa 2011, 256-57). }\end{array}$ & \\
\hline 1695 & 8th month & $\begin{array}{l}\text { Yoshiyasu receives a kasaya robe from Gaoquan (Miya- } \\
\text { kawa 2011, 255). }\end{array}$ & \\
\hline
\end{tabular}




\begin{tabular}{|c|c|c|}
\hline & Date & Contact \\
\hline 1696 & $\begin{array}{l}\text { 7th day of } 6 \text { th } \\
\text { month }\end{array}$ & $\begin{array}{l}\text { Qiandai Xing'an (Jp. Sengai Shōan, 1636-1705) is in Edo } \\
\text { to thank the shogun for his appointment as sixth abbot } \\
\text { of Manpukuji (Otsuki et al. 1988, 363). Yoshiyasu } \\
\text { invites him to his residence. Xuean Hairun (Jp. Sekken } \\
\text { Kaijun, 1649-1708) accompanies Qiandai. A brush talk } \\
\text { takes place, a copy of which survives in Rakushido } \\
\text { nenroku (Miyakawa 2013, 24-26). }\end{array}$ \\
\hline 1696 & $\begin{array}{l}\text { 13th day of } 6 \text { th } \\
\text { month }\end{array}$ & $\begin{array}{l}\text { Qiandai visits Yoshiyasu again and there is a } \\
\text { question-and-answer dialogue, plus an exchange of } \\
\text { poems, both preserved in Rakushido nenroku (Miya- } \\
\text { kawa } 2013,30-32 \text { ). }\end{array}$ \\
\hline 1696 & $\begin{array}{l}\text { 20th day of } 6 \text { th } \\
\text { month }\end{array}$ & $\begin{array}{l}\text { Yoshiyasu and Qiandai, together with Xuean, converse } \\
\text { using brush talk. Qiandai raises the subject of new } \\
\text { restrictions for controlling the behavior of Obbaku } \\
\text { monks, and Yoshiyasu offers his suggestions (Miyakawa } \\
\text { 2013, 33-35; 2007, 260-61). }\end{array}$ \\
\hline 1698 & $\begin{array}{l}\text { 4th day of } 11 \text { th } \\
\text { month }\end{array}$ & $\begin{array}{l}\text { Qiandai is in Edo to thank the shogun for the Purple Robe } \\
\text { (Ötsuki et al. 1988, 363). Yoshiyasu invites Qiandai to } \\
\text { his residence, where they converse using brush talk. } \\
\text { They exchange letters numerous times afterwards } \\
\text { (Miyakawa 2013, 198). }\end{array}$ \\
\hline 1705 & $\begin{array}{l}\text { 23rd day of } 5 \text { th } \\
\text { month }\end{array}$ & $\begin{array}{l}\text { Yueshan Daozong (Jp. Essan Dōshū, 1629-1709) is in } \\
\text { Edo thanking the shogun for his appointment as sev- } \\
\text { enth abbot of Manpukuji (Ōtsuki et al. 1988, 363). } \\
\text { Yoshiyasu receives him, and they converse using brush } \\
\text { talk, which is preserved in Rakushido nenroku (SHJ } \\
\text { 1915, 32:36r-39r). }\end{array}$ \\
\hline
\end{tabular}

Notes

Another copy of the brush talk conversation, written in the hand of Andō Tōya, survives in the Manpu-

kuji collection (Tsuji 1947, 249-50).

uean, who was from Nanjing, arrived in Nagasaki in 1667. When he accompanied Qiandai on his mission of thanks, Xuean was asked to perform a reading from the Daxue and to write calligraphy (Ötsuki et al. 1988, 176). 
1707 29th day of 12th month

1708 1st day of 3rd month

1708 2nd day of 3rd month (Yuefeng residing at

Rikugien)

1708 24th day of 3rd month Yuefeng residing at Rikugien)

1708 28th day of 3rd month (Yuefeng residing at Rikugien)
Yuefeng Daozhang (Jp. Eppō Dōshō, 1655-1734), eighth abbot of Manpukuji, is in Edo to thank the shogun for the Purple robe (Ötsuki et al. 1988, 43). He meets with Yoshiyasu, as described in detail in Matsukage nikki. After Yuefeng returns to Manpukuji, Yoshiyasu and Yuefeng continue to communicate by letter (Miyakawa 2007, 910-11).

Yoshiyasu invites Yuefeng to his suburban estate, the Rikugien (SHJ 1915, 47:2v). Yuefeng stays with Yoshiyasu for five weeks (Miyakawa 2007, 931, 932n8).

Yoshiyasu and Yuefeng converse at Rikugien by means of brush talk (Miyakawa 2007, 927; SHJ 1915, 47:3r).

Yuefeng visits the shogunal castle, where he answers questions in spoken Chinese and a Japanese monk interprets (SHJ 1915, 47:11v). Yoshiyasu is said to be the only one to understand the gist of the conversation without the need for translation (SHJ 1919, 59:13r-15r).

Yuefeng and Yoshiyasu exchange poems (Tsuji 1947, 252-53).
The exact date of this meeting is not given in Matsukage nikki, but it is likely that it took place on the occasion of Yuefeng's second visit to Edo, when he thanked the shogun for the Purple Robe, rather than during his visit to offer thanks for his appointment as abbot in the 8th month of 1707 . This is because the Matsukage nikki account comes at the end of 1707 .

Tsuji gives the date of Yoshiyasu's invitation as the 1st day of the 3rd month of 1708 (Tsuji 1947, 250). Tsuji's source is unclear. The precise date is not recorded in Rakushido nenroku, but according to Matsukage nikki it occurred sometime at the beginning of the 3rd month ("yayoi no hajime nari keri," Miyakawa 2007, 925).

Yoshiyasu has one of his retainers, Tanaka Tōkō (1668-1742) make a copy of the conversation, and this is preserved in Manpukuji. A modern transcription is available in Tsuji $(1947,251-52)$.

See also Tsuji (1947, 249); Ishizaki (1940, 50).

These poems are preserved in the Shinkōin, the mortuary temple of Yoshiyasu's wife Sadako. A modern transcription is available in Tsuji (1947, 252-53). 
Appendix 1. (contd.)

\begin{tabular}{|c|c|c|c|}
\hline & Date & Contact & Notes \\
\hline 1708 & $\begin{array}{l}2 \text { nd day of } 4 \text { th } \\
\text { month (Yuefeng } \\
\text { residing at } \\
\text { Rikugien) }\end{array}$ & Yuefeng and Yoshiyasu exchange poems (Tsuji 1947, 253). & $\begin{array}{l}\text { According to Tsuji, Sadako’s mortuary temple also } \\
\text { contains some forty or so letters to Yuefeng from } \\
\text { Yoshiyasu or his retainers, including Ogyū Sorai, } \\
\text { Andō Tōya, and Tanaka Tōkō. }\end{array}$ \\
\hline 1709 & $\begin{array}{l}\text { 3rd day of } 6 \text { th } \\
\text { month }\end{array}$ & $\begin{array}{l}\text { Yoshiyasu writes to Yuefeng announcing his retirement } \\
\text { (Tsuji 1947, 254). }\end{array}$ & $\begin{array}{l}\text { Yoshiyasu's decision to retire is detailed in Matsukage } \\
\text { nikki (Miyakawa 2007, 1012). }\end{array}$ \\
\hline 1709 & $\begin{array}{l}\text { 10th day of } 10 \text { th } \\
\text { month }\end{array}$ & $\begin{array}{l}\text { Yuefeng is in Edo to celebrate the appointment of a new } \\
\text { shogun (Ōtsuki et al. 1988, 363). Yoshiyasu invites } \\
\text { Yuefeng to Rikugien and takes Buddhist vows with } \\
\text { Yuefeng as his master. Yoshiyasu's wife Sadako also } \\
\text { takes vows at this time (Miyakawa 2007, 1065; Tsuji } \\
\text { 1947, 254). }\end{array}$ & \\
\hline
\end{tabular}

